\title{
Community Empowerment School Closure Localization Dolly in Kelurahan Putat Jaya Sawahan Surabaya
}

\author{
${ }^{1}$ Wiwik Handayani, ${ }^{2}$ Sri Mulyaningsih, ${ }^{3}$ Wiludjeng Widayati \\ ${ }^{123}$ University of Pembangunan Nasional "Veteran" East Java \\ Wiwik.em@upnjatim.ac.id
}

\begin{abstract}
The closure of the localization of Dolly has issues of its own for the surrounding community or communities affected. This is due to the lack of the skills possessed by the localization community around, causing the decline in family income. Through the activities of the service are expected to improve the skills of the community affected and its revenues. Activities include training in entrepreneurship, dedication to the creation of creative effort, packaging, processing of catfish into a dumpling, nugget and mince. The selection of catfish as a base material because the Catfish is easy to get, cheap and easily cultivated by rural communities as well as urban areas. In addition to the fish is a very good protein for growing children and also adults because of low colesterol. Training activities are conducted four times by way of direct practice so that they really can do it yourself after you finish training. In an effort to increase revenue, after completion of the training the participants were required to produce and sell it as well as do mentoring. Thus the process of evaluation and monitoring will belp affected communities business growth.
\end{abstract}

Keywords: Communities empowerment, fish processing, packaging entrepreneurship, income generation, community development

\section{Pendahuluan}

Pembangunan Nasional akan tercapai apabila pembangunan di daerah juga berjalan dengan baik. Namun kenyataan angka kemiskinan masih tinggi yang akan mengganggu stabilitas Nasional. Untuk itu pemerintah sedang menggalakkan kegiatan yang berhubungan dengan penurunan angka kemiskinan. Salah satu upaya yang dilakukan adalah dengan melakukan pemberdayaan'1. Bahri, Efri. S. berpendapat bahwa pemberdayaan merupakan upaya untuk meningkatkan pendapatan sehingga akan mengurangi angka kemiskinan. Kemiskinan merupakan masalah sosial yang tidak ada habisnya di negeri ini. Namun pemerintah tetap berusaha untuk menguranginya atau mengatasi melalui berbagai program. ${ }^{2}$ Menurut Siagian, pembangunan merupakan usaha atau rangkaian usaha pertumbuhan dan perubahan yang dilakukan secara sadar oleh suatu bangsa, Negara dan pemerintah untuk menuju modernitas dalam rangka pembinaan bangsa (National Building). ${ }^{3}$ Agus Suryono, berpendapat setidaknya terdapat lima persyaratan pembangunan, antara lain: Kemampuan, Kebersamaan, Kekuasaan, Ketahanan, serta Saling

1 Ani Wulandari, "Influence of Education and Work Experience on Work Motivation and Job Performance at Branch Office of BANK J Trust Bank Surabaya," THE SPIRIT OF SOCIETY JOURNAL 1, no. 1 (n.d.): 12-20, accessed November 2, 2017, http://jurnal.narotama.ac.id/index.php/scj/article/view/364.

2 Efri.S Bahri, Pemberdayaan, Konsep Dan Aplikasi (Forum Aktif Menulis (FAM) Indonesia, 2013).

${ }^{3}$ Sondang P Siagian, Administrasi Pembangunan, Konsep, Dimensi Dan Strateginya (Jakarta: Bumi Aksara, 2008). 
ketergantungan. ${ }^{4}$ Ada hubungan antara pemberdayaan dengan tingkat keberdayaan masyarakat. ${ }^{5}$ Sedangkan menurut Sumodiningrat, ${ }^{6}$ peningkatan kesejahteraan umum masyarakat merupakan suatu inti dari sasaran pembangunan. Suatu pembangunan bisa dikatakan berhasil apabila mampu mengangkat derajat rakyat sebanyak mungkin pada tatanan kehidupan ekonomi yang lebih baik dan layak. Banyaknya permasalahan yang terjadi terkait peningkatan angka kemiskinan memberikan peluang bagi akademisi untuk terus ikut berupaya mengentaskan kemiskinan melalui program-program pengabdian terhadap masyarakat?

Kelurahan Putat Jaya Surabaya yang merupakan lokalisasi terbesar di Asia Tenggara. Namun tahun 2014 yang lalu lokalisasi di Kelurahan Putat Jaya Kecamatan Sawahan Surabaya resmi ditutup oleh Walikota Surabaya. Adanya penutupan lokalisasi ini ada sebagian masyarakat terdampak yang menyesalkan karena kehilangan mata pencaharian sebagai penghidupannya. Hal ini juga ditunjukkan adanya peningkatan kemiskinan di wilayah Kelurahan Putat Jaya Surabaya. Jumlah penduduk Putat Jaya sebanyak $14.207 \mathrm{kk}$ dengan jumlah penduduk miskin sebanyak $1.549 \mathrm{kk}$. Sedangkan warga terdampak sebanyak 1.000 kk (sumber: data Kelurahan Putat Jaya).

Secara demografi wilayah Putat Jaya merupakan wilayah padat penduduk dengan mata pencaharian terbanyak berdagang dan buruh pabrik. Jadi jika dilihat potensi wilayah maka potensinya adalah sumber daya manusia. Jumlah penduduk yang banyak dan tidak punya potensi kekayaan alam maka hanya dapat diselesaikan dengan melakukan pemberdayaan masyarakat. Salah satu upaya yang dilakukan oleh akademisi melalui program pengabdian masyarakat memberikan ketrampilan untuk melakukan olahan ikan lele dan menanamkan jiwa kewirausahaan. Ikan lele dipilih karena kaya protein, harganya murah atau terjangkau, mudah didapatkan, dan mudah dibudidayakan. Sehingga bisa berjalan beriringan antara pengolahan ikan dan perikanan di kota. Berdasarkan kondisi dan situasi wilayah maka progam pengabdian yang cocok adalah pemberdayaan masyarakat melalui kewirausahaan dan pengolahan ikan menjadi produk variatif dan produktif.

\section{Metode}

Kegiatan pengabdian kepada masarakat ini menggunalkan metode community development atau pengembangan masyarakat. Strategi ini digunakan untuk meningkatkan kemampuan warga terutama ibu-

${ }^{4}$ Agus Suryono, Pengantar Teori Pembangunan (Malang: Universitas Negeri Malang, 2004).

${ }^{5}$ Kesi Widjajanti, "Model Pemberdayaan Mas yarakat," Jurnal Ekonomi Pembangunan 12, no. 1 (2011): 15-27.

6 Gunawan Sumodiningrat, Pemberdayaan Masyarakat Dan Jaring Pengamanan Sosial (Yogyakarta: Ghalia Indonesia, 1999).

7 Arasy Alimudin et al., "The Factors Affecting Land Prices In Housing Location In Sidoarjo Regency," International Journal of Society Development and Engagement 1, no. 1 (2017): 2597-4777.

Volume 1, Number 2, November 2017 | 211 
ibu rumah tangga warga terdampak pasca pembubaran lokalisasi Dolly. Dalam kegiatan pengabdian ini melibatkan Kepala Kelurahan Putat Jaya yang memberikan ijin untuk melakukan pengabdian di Wilayahnya. Ibu-ibu rumah tangga warga RW 11 RT.7 kelurahan Putat Jaya yang terdampak pembubaran Lokalisasi Dolly. Pelatihan Dilakukan di Balai RT.7 pada hari Sabtu mulai pukul 09.00-14.00 selama bulan September 2017

\section{Hasil dan Diskusi}

Kewirausahaan adalah kemampuan untuk menciptakan sesuatu yang baru dan berbeda. Definisi lain adalah proses penerapan kreativitas dan keinovasian dalam memecahkan permasalahan dan menemukan peluang untuk memperbaiki kehidupan usaha. Hal yang sangat diperlukan dalam kewirausahaan adalah kreativitas, inovasi, mengerjakan sesuatu yang baru atau dalam jumlah baru. Untuk menjadi entrepreneur sukses: 1) harus memiliki keinginan untuk sukses, 2) percaya diri dan memiliki keyakinan untuk mencapai target yang ingin dicapai, 3) inovatif dan terbuka untuk ide-ide baru dengan meninggalkan cara-cara lama serta menggunakan teknologi baru, 4) semangat untuk melakukan bisnis, 5) bersedia menghadapi persaingan, 6) mampu menerima kritikan yang membangun dan konstruktif, 7) berani mengambil resiko dan dapat mengambil keputusan tepat yang menguntungkan. ${ }^{8}$

Menumbuhkan motivasi melaui komunikasi, bermimpi, membuka mata, membangun hubungan dengan sesama, pengalaman, pendidikan/ pengetahuan/ ketrampilan; inovatif, kreatif, penerapan / tindakan. Selanjutnya instruktur memberikan pelatihan cara pengemasan sederhana. Pelatihan ini diberikan agar peserta pelatihan memiliki kemampuan pengemasan produk yang sehat dan menarik.

Pengemasan merupakan bagian dari upaya memasarkan produk. Seperti dijelaskan oleh Kotler dan Keller bahwa upaya pemasaran dapat dilakukan melalui 4P yaitu price, product, promotion and place. 9 Artinya bagaimana kita bisa memyesuaikan aplikasi 4P kepada pembeli. Dalam membuat kemasan ada beberapa hal yang diperhatikan: 1) warna kemasan, 2) bentuk kemasan, 3) bahan kemasan, 4) desain kemasan, 4) ukuran kemasan. Menurut Vardhan dan Amulya kemasan merupakan kebutuhan utama bagi konsumen produk makanan siap saji.10 Jadi kemasan juga menjadi bahan pertimbangan ketika konsumen ingin melakukan pembelian. Untuk produk-produk makanan juga diperlukan kemasan yang tidak mengganngu kesehatan.

${ }^{8}$ Kasmir, Kewirausahaan (Jakarta: PT Raja Grafindo Persada, 2010).

9 Philip Kotler and Keller, Marketing Management (Prentice Hall: Pearson Education, 2012).

10 G. Harsa Vardhan and M. Amulya, "Visual Influence of Packing on Consumer Buying Behavior of Ready To Eat Food Products," Journal of Business and Management 19, no. 7 (2017).

Volume 1, Number 2, November 2017 | 212 
Ikan lele merupakan salah satu makanan favorit di Indonesia. Selain harganya murah, rasanya juga sangat enak. Meski demikian, ada sebagian masyarakat yang takut menikmati masakan dari ikan air tawar tersebut. Kandungan gizi ikan lele per 100 gram adalah 84 kalori; 14,8 protein; 2,3 lemak; 0,3 zat besi. ${ }^{11}$ Di Indonesia sendiri para peternak sering mengembangbiakan serta membesarkan ikan lele di kolam atau tambak. Kolam tersebut selalu dijaga agar bebas dari pencemaran dan jauh dari pusat buangan limbah. Makanan yang diberikan juga merupakan makanan khusus untuk ikan lele. Jadi tetap aman dikonsumsi dan tidak akan menimbulkan masalah pada kesehatan.

Salah satu cara paling populer memasak ikan lele adalah dengan cara digoreng. Banyak yang tidak tahu bahwa teknik penggorengan yang salah dapat menyebabkan lele yang dikonsumsi menjadi sumber munculnya serangan penyakit dan yang paling utama yaitu penyakit kanker. Kesalahan paling fatal yang paling sering terjadi ialah pada penggunaan minyaknya. Minyak yang digunakan untuk menggoreng ikan lele harus bebas dari kandungan kolesterol maupun zat berbahaya lainnya. Meski ikannya dibudidaya dengan cara yang benar dan dibersihkan sebelum dimasak, namun ketika minyak penggorengannya tidak sehat tetap bisa memunculkan serangan penyakit. Dari sini tentu kita menjadi paham jika sumber datangnya penyakit tersebut tidak berasal dari ikan lele sendiri melainkan minyaknya. Jadi kesimpulannya, jika dipelihara dengan cara yang benar dan kolamnya selalu bersih serta bebas dari pencemaran maka ikan lele tetap aman dikonsumsi. Demikian pula dengan sistem pengolahannya harus dicuci hingga bersih sebelum dimasak.
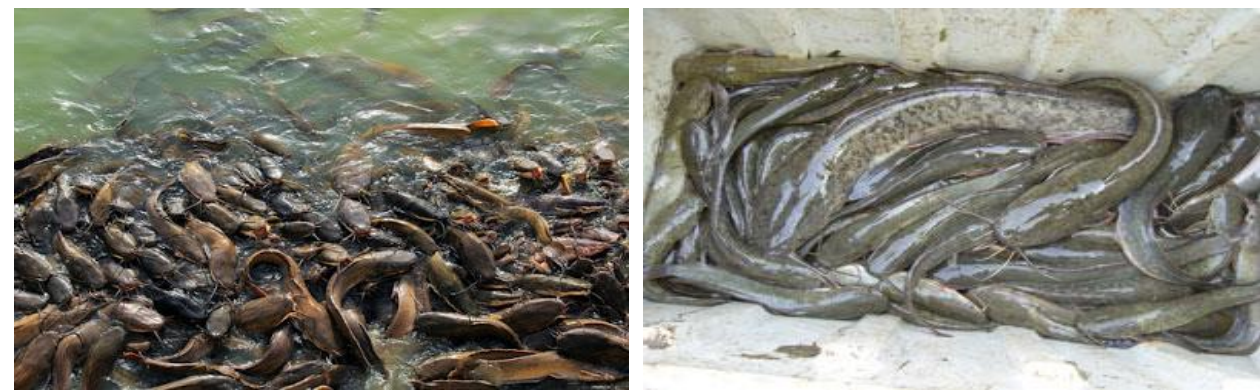

Gambar 1. Ikan Lele ${ }^{12}$

\section{Pelaksanaan Pelatihan}

Dalam rangka melaksanakan program pengabdian kepada masyarakat berbentuk pelatihan ini dilaksanakan dengan metode sebagai berikut:

11 Survey Sosial Ekonomi Nasional, 2013-BPS 2010 lele.html

12 Sumber gambar: http://www.kopi-ireng.com/2016/04/fakta-d an-informasi-menarik-mengenai-ikan- 
ENGAGEMENT

Jurnal Pengabdian Kepada Masyarakat

ISSN : 2579-8375 (Print)

ISSN : 2579-8391 (Online)
This work is licensed under a Creative Commons

Attribution-ShareAlike 4.0 International License. CC BY SA

1. Proses penyajian materi menggunakan cara pembelajaran orang dewasa sepert: ceramah, diskusi dan tanya jawab. Dengan metode pembelajaran tersebut diharapkan mereka mampu meningkatkan motivasi untuk mengolah ikan lele dengan berbagai variasi dan produktif, mampu melakukan pengemasan dan mampu menjual, serta mampu berwirausaha.

2. Metode praktek dan pendampingan

Pada metode ini peserta diberikan pembelajaran dan langsung praktek mengolah ikan lele dengan tiga macam jenis makanan.

Adapun pelatihan yang dilakukan adalah:

1. Pelatihan Tentang Manajemen Kewirausahaan, Pengemasan Sederhana dan Penciptaan Usaha Kreatif Pada warga Rw 11 di Kelurahan Putat Jaya Surabaya. Dilaksanakan tanggal 2 September 2017

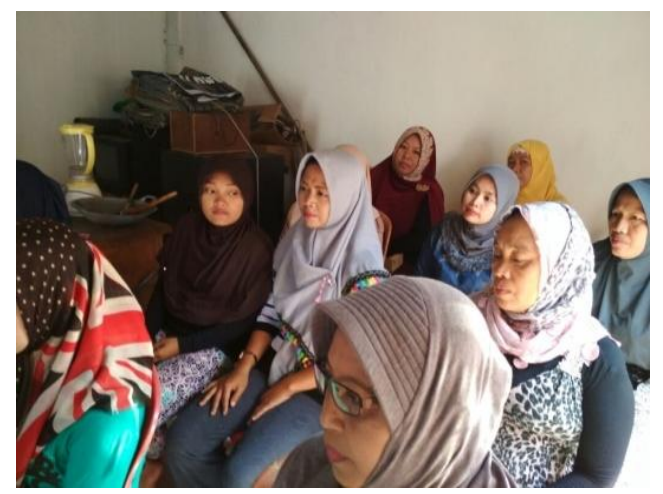

Gambar 2: Pelatiban Manajemen Kewirausahaan, Pengemasan Sederhana dan Penciptaan Usaha Kreatif

Pada Gambar 2. Peserta pelatihan sedang mendengarkan dan memperhatikan penjelasan dari instruktur yang menjelaskan tentang Manajemen Kewirausahaan, Pengemasan Sederhana dan Penciptaan Usaha Kreatif.

2. Pelatihan Pembuatan Siomay Ikan Lele (SIOMLE) Pada warga Rw 11 di Kelurahan Putat Jaya Surabaya. Dilaksanakan tanggal 9 September 2017

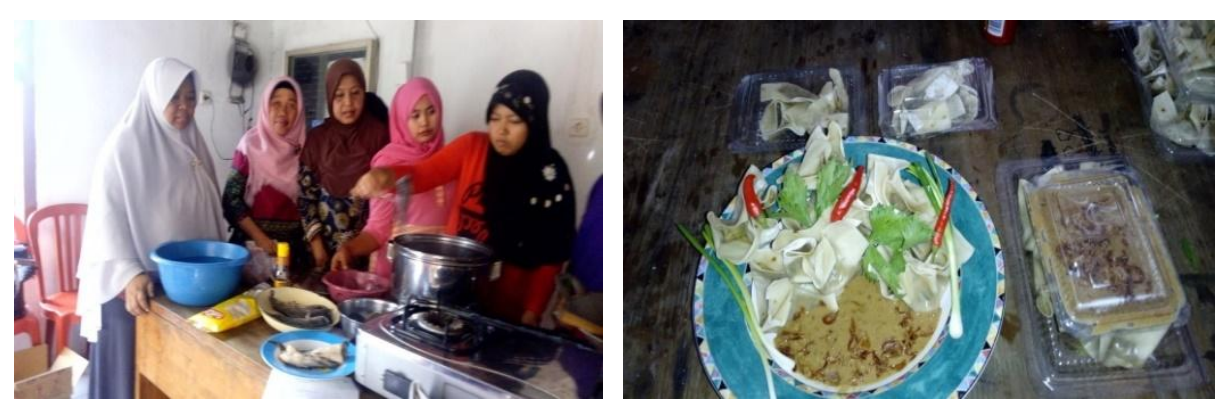

Gambar 3: Pembuatan Siomay Ikan Lele (SIOMLE) 
ENGAGEMENT

Jurnal Pengabdian Kepada Masyarakat

ISSN : 2579-8375 (Print)

ISSN : 2579-8391 (Online)
This work is licensed under a Creative Commons

Attribution-ShareAlike 4.0 International License. CC BY SA

Pada gambar 3. menunjukkan warga RW 11 peserta pelatihan yang sedang mendengarkan dan memperhatikan penjelasan dari instruktur yang menjelaskan Pelatihan Pembuatan Siomay Ikan Lele (SIOMLE)

Pelatihan ini sejalan dengan Andriani, T. yang menjelaskan bahwa pengolahan ikan dengan berbagai variasi akan meningkatkan gizi dan mengurangi makanan instan. Pada pelatihan ini, instruktur memberikan cara membuat siomay dari ikan Lele. ${ }^{13}$

3. Pelatihan Pembuatan Nugget Ikan Lele (NUGGLE) Pada warga Rw 11 di Kelurahan Putat Jaya Surabaya. Dilaksanakan tanggal 16 September 2017
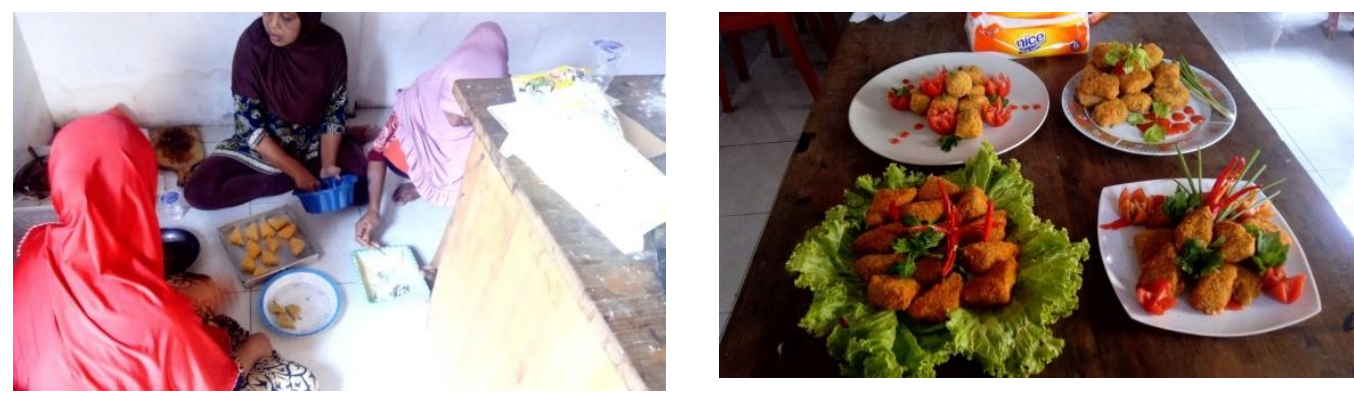

Gambar 4: Pembuatan Nugget Ikan Lele (NUGGLE)

Pada gambar 4. menunjukkan warga RW 11 peserta pelatihan yang sedang mendengarkan dan memperhatikan penjelasan dari instruktur yang menjelaskan Pembuatan Nugget Ikan Lele (NUGGLE).

4. Pelatihan Pembuatan Abon Ikan Lele (ABILE) Pada warga Rw 11 di Kelurahan Putat Jaya Surabaya. Dilaksanakan tanggal 23 September 2017
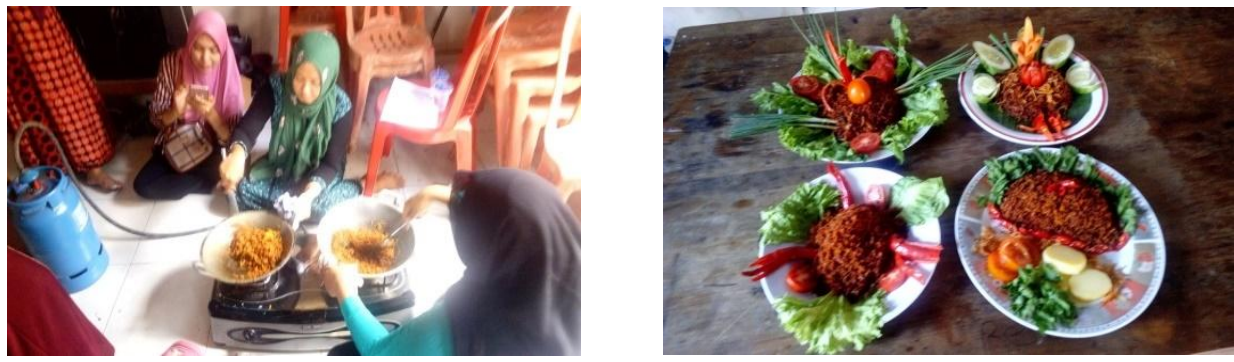

Gambar 5: Pembuatan Abon Ikan Lele (ABILE)

Pada gambar 5. menunjukkan warga RW 11 peserta pelatihan yang sedang mendengarkan dan memperhatikan penjelasan dari instruktur yang menjelaskan Pembuatan Abon Ikan Lele (ABILE).

13 Tuti Andriani, "Pengolahan Ikan Pati Menjadi Makanan Variatif Dan Produktif Di Desa Sawahan Kecamatan Kampar Utara Kabupaten Kampar,” Jurnal Kewirausahaan 13, no. 1 (2014): 1-16.

Volume 1, Number 2, November 2017 | 215 


\section{Kegiatan Monitoring Pertama}

Kegiatan monitoring ini dilakukan sebagai tindak lanjut kegiatan setelah pelatihan selesai. Di gunakan sebagai tindakan untuk mengevaluasi hasil pelatihan sekaligus memantau perkembangan penerapan hasil pelatihan.
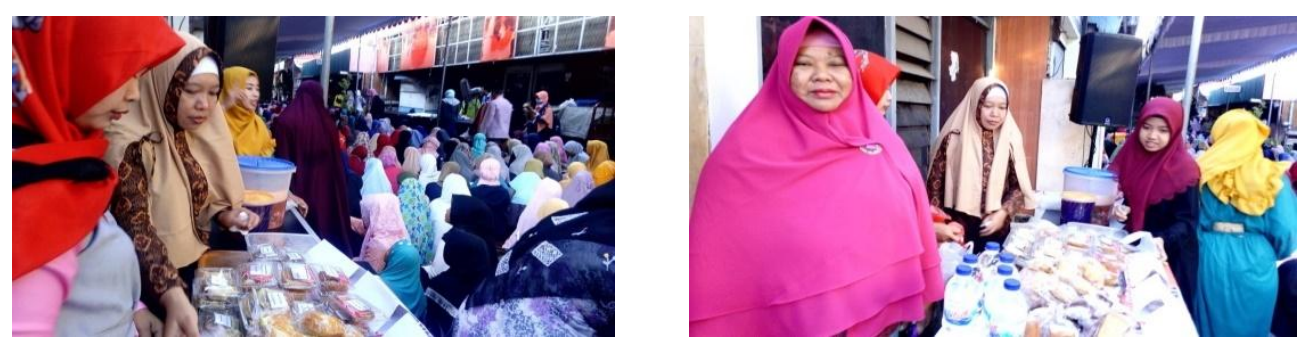

\section{Gambar 6. Monitoring peserta pelatihan ketika menjual produk hasil pelatihan}

Pada gambar 6. menunjukkan warga RW 11 peserta pelatihan sedang melakukan penjualan produk hasil pelatihan dan instruktur sedang melakukan monitoring. Sebagai pembelajaran awal melakukan penjualan di acara-acara tertentu seperti bazar. Terlihat dalam foto bahwa peserta pelatihan sedang melakukan penjualan pada bazar saat ada pengajian di gang Dolly. Ini merupakan bentuk tumbuhnya semangat dan jiwa kewirausahaan. Selanjutnya mereka akan mampu membuat bisnis plan yang mampu menghasilkan pendapatan. Kegiatan monitoring setelah pelaksaan pelatihan sangat diperlukan. Hal Ini sejalan dengan Kurniawati, D.P., et. al. yang menyarankan bahwa meningkatkan interaksi dengan masyarakat yang memperoleh hibah dan meningkatkan monitoring. ${ }^{14}$ Dengan demikian maka kegiatan yang dilakuan oleh masyarakat pasca pelatihan dapat terus dipantau guna keberlanjutan program.

\section{Kesimpulan}

Pelatihan yang diadakan sangat bermanfaat untuk peserta pelatihan, dan memberi pengaruh yang positif terhadap pengetahuan dan kemampuan ibu-ibu peserta pelatihan. Setelah diberikan pelatihan kewirausahaan maka ibu-ibu peserta pelatihan memiliki semangat untuk mengembangkan hasil pelatihan dengan memasarkan hasil produksinya pada basar yang dilakukan di Gang Dolly tanggal 1 0ktober 2017. Ini merupakan langkah awal untuk dapat mengembangkan usahanya sehingga dalam jangka panjang akan mampu meningkatkan pendapatan di rumah tangga mereka masing-masing. Kegiatan pemantauan dilakukan oleh instruktur pelatihan secara berkala untuk memberikan pendampingan dan mengevaluasi untuk keberlanjutan usaha ibu-ibu RW 11 peserta pelatihan.

14 Kurniawati et al., "Pemberdayaan Masyarakat Di Bidang Usaha Ekonomi: Studi Pada Badan Pemberdayaan Mas yarakat Kota Mojokerto," Jurnal Administrasi Publik (JAP) 1, no. 4 (2014): 9-14.

Volume 1, Number 2, November 2017 | 216 
This work is licensed under a Creative Commons Attribution-ShareAlike 4.0 International License. CC BY SA

Pada pengabdian selanjutnya akan diberi pelatihan: 1) Pelatihan manajemen untuk membangun hubungan pemasaran berkelanjutan dengan mitra. Hal ini untuk memudahkan memasarkan produk (hasilhasil pelatihan ) dengan lebih mudah. 2) Pelatihan untuk pengemasan produk untuk dipasarkan dengan skala lebih besar. Pelatihan ini untuk memberikan pengetahuan tentang cara pengemasan yang menarik agar dapat menarik konsumen. 3). Pelatihan pembuatan Merk dan membantu mendaftarkan ke Badan Pom dan Dinas Perindustrian. Pelatihan ini untuk memberikan pengetahuan tentang Merk agar dapat membuat merk yang mudah dikenal, diingat, dan dikenang. Hal ini agar mampu menarik pembeli produkproduk hasil pelatihan. Apabila hasil-hasil produk pelatihan dapat dilakukan secara berkelanjutan maka akan mampu menumbuhkan UKM baru.

\section{Daftar Referensi}

Alimudin, Arasy, Partomi Simangunsong, Muh Barid, and Nizaruddin Wajdi. "The Factors Affecting Land Prices In Housing Location In Sidoarjo Regency." International Journal of Society Development and Engagement 1, no. 1 (2017): 2597-4777.

Andriani, Tuti. "Pengolahan Ikan Pati Menjadi Makanan Variatif Dan Produktif Di Desa Sawahan Kecamatan Kampar Utara Kabupaten Kampar.” Jurnal Kewirausahaan 13, no. 1 (2014): 1-16.

Bahri, Efri.S. Pemberdayaan, Konsep Dan Aplikasi. Forum Aktif Menulis (FAM) Indonesia, 2013.

Kasmir. Kewirausahaan. Jakarta: PT Raja Grafindo Persada, 2010.

Kotler, Philip, and Keller. Marketing Management. Prentice Hall: Pearson Education, 2012.

Kurniawati, D.Praptiwi, Supriyono, Bambang, and Imam Hanafi. "Pemberdayaan Masyarakat Di Bidang Usaha Ekonomi: Studi Pada Badan Pemberdayaan Masyarakat Kota Mojokerto.” Jurnal Administrasi Publik (JAP) 1, no. 4 (2014): 9-14.

Sondang P Siagian. Administrasi Pembangunan, Konsep, Dimensi Dan Strateginya. Jakarta: Bumi Aksara, 2008.

Sumodiningrat, Gunaw an. Pemberdayaan Masyarakat Dan Jaring Pengamanan Sosial. Yogyakarta: Ghalia Indonesia, 1999.

Suryono, Agus. Pengantar Teori Pembangunan. Malang: Universitas Negeri Malang, 2004.

Vardhan, G. Harsa, and M. Amulya. "Visual Influence of Packing on Consumer Buying Behavior of Ready To Eat Food Products." Journal of Business and Management 19, no. 7 (2017).

Widjajanti, Kesi. “Model Pemberdayaan Masyarakat.” Jurnal Ekonomi Pembangunan 12, no. 1 (2011): 15-27.

Wulandari, Ani. "Influence of Education and Work Experience on Work Motivation and Job Performance at Branch Office of BANKJ Trust Bank Surabaya." THE SPIRIT OF SOCIETY JOURNAL 1, no. 1 (n.d.): 12-20. Accessed November 2, 2017. http://jurnal.narotama.ac.id/index.php/scj/article/view/364. 